\title{
A revision of Metriorrhynchus from the Philippines with molecular evidence of an Australian origin of the Oriental Metriorrhynchus fauna (Coleoptera: Lycidae)
}

\author{
LAdisLav BOCÁK ${ }^{1,3}$, KIYOSHI MATSUDA² and TAKASHI YAGI ${ }^{3}$ \\ ${ }^{1}$ Department of Zoology, Faculty of Science, Palacký University, tř. Svobody 26, 77146 Olomouc, Czech Republic; \\ e-mail: ladislav.bocak@upol.cz \\ ${ }^{2}$ Department of Human and Environmental Sciences, Osaka Shin-Ai College, 6-2-28 Tsurumi, Tsurumi-ku, Osaka, 538-0053, Japan \\ ${ }^{3}$ Research Institute for Advanced Science and Technology, Osaka Prefecture University, 1-2 Gakuen-cho, Sakai, Osaka, 599-8570, \\ Japan
}

Key words. Coleoptera, Lycidae, Metriorrhynchinae, mtDNA, COI, ND5, new species, new combinations, key, Oriental Region

\begin{abstract}
The Metriorrhynchus fauna of the Philippines is revised. All known species are redescribed and seven new species are added: M. isarogensis sp. n., M. menieri sp. n., M. mindanaoensis sp. n., M. newbataanensis sp. n., M. ochii sp. n., M. palawanensis sp. n., and M. takedai sp. n. Additionally, M. yoshioi sp. n. is described from Sulawesi. Xylobanus longissimus Pic, 1922 is transferred to Metriorrhynchus, and Metriorrhynchus pallidus (Dalman in Schoenherr, 1818) is transferred to Leptotrichalus Kleine, 1925. The dispersal routes and speciation of Metriorrhynchus from the Philippines, Sulawesi and the Oriental Region were studied using mtDNA markers. One dispersal event is supposed for establishing of the Greater Sunda Islands fauna and another one for the Philippine fauna. Both faunas underwent speciation in the respective areas and all species show high degree of endemism. The Metriorrhynchus in Palawan is of Philippine origin in contrast with the tectonic history of Palawan and its connection with Borneo during the last glacial maximum.
\end{abstract}

\section{INTRODUCTION}

The Philippine fauna of Lycidae was studied by Kleine (1926) and recently only Microtrichalus Pic, 1921 and Diatrichalus Kleine, 1926 were revised (Bocák, 1998, 2000). Unlike the continental part of the Oriental Region and the area of the Greater Sunda Islands, the fauna of the Philippines shows a much stronger connection to the Moluccas, Sulawesi and New Guinea as shown by the high proportion of genera dispersed from the Australian Region. With the exception of the Trichalina, the genera Metriorrhynchus Gemminger \& Harold, 1869 and Cautiromimus Pic, 1926 are the most prominent representatives of the Australian faunistic element. The genera of Afrotropical origin are represented by Cautires Waterhouse, 1879, Xylobanus Waterhouse, 1879, and Bulenides Waterhouse, 1879 (Bocák, 2002).

Kleine (1933) listed in his World Catalogue six species of Metriorrhynchus in the Philippines and adjacent islands. Although Kleine used male genitalia as a source of diagnostic characters, he usually dissected only the holotype after he defined morphospecies by external characters. As many similarities are produced by mimicry in the evolution of Lycidae, a surprisingly high number of species remained undiscovered and the number of species in the area was considerably underestimated.

The task of this study is to provide a taxonomic revision of Metriorrhynchus species from the Philippines and to construct the species level phylogeny to show the relationships between faunas of the Australian and Oriental Regions.

\section{MATERIAL AND METHODS}

\section{Taxonomy}

Both male and female genitalia of all available type specimens were dissected and membranous parts stained lightly with chlorazol black. Important characters were drawn using an ocular grid-screen or illustrations were derived from photographs taken with a digital camera attached to a stereoscopic microscope.

Depositories: MHMB - Natural History Museum, Basel; BMNH - Natural History Museum, London; MNHN - Muséum National d'Histoire Naturelle, Paris; EIHU - Zoological Museum of the Hokkaido University, Sapporo; NHRS - Naturhistoriska Riksmuseet, Stockholm; SMTD - Staatliches Museum für Tierkunde, Dresden; ZMPA - Muzeum i Instytut Zoologii PAN, Warsaw; LMBC - collection of Ladislav Bocák, KMTC - collection of Kiyoshi Matsuda.

Abbreviations: $\mathrm{BL}$ - body length, $\mathrm{WH}$ - width of humeri, PL - pronotum length, PW - pronotum width, Edist - minimum frontal distance between eyes, Ediam - maximum eye diameter.

\section{Molecular phylogeny}

Taxon sampling and sequence determination

The sampling was far from complete due to the shortage of well-preserved material, but the fauna of each area of interest was represented by several species. Only females represented four Metriorrhynchus species, which we sequenced, and we were not able to connect them with the morphologically based species. Altogether we sequenced four species from the Philippines, four from Sulawesi, two from Java and continental Asia, and three from New Guinea. Representatives of four genera formed the outgroup: Cautiromimus (1 sp.), Cladophorus (1 sp.), Porrostoma (2 spp.) and three species of a still undescribed genus from Sulawesi. The list of specimens is given in Table 1.

Most specimens were preserved in alcohol and total DNA was extracted from thoracic muscles and legs by the phenol:chloro- 
TABLE 1. Specimens included in the study.

\begin{tabular}{|c|c|c|c|}
\hline \multirow{2}{*}{ Species } & \multirow{2}{*}{ Locality data } & \multicolumn{2}{|c|}{ EMBL Accession No. } \\
\hline & & COI & ND5 \\
\hline Cautiromimus sp. & New Guinea, Biak, Nerun, Korim, 16.xii.2000, A. Riedel lgt. & DQ144680 & DQ144704 \\
\hline Cladophorus sp. & New Guinea, Wasior, Wonoliwoi, 500, 3.-5.i.2001, A. Riedel lgt. & DQ144681 & DQ144705 \\
\hline Metriorrhynchini gen. sp. (1) & Sulawesi, 20 km NE Sabbang, 400 m, 5.-7.vii.2001, Bolm lgt. & DQ144682 & DQ144706 \\
\hline Metriorrhynchini gen. sp. (2) & Sulawesi, 38 km SE Pendolo, 1200 m, 10.-11.vii.2001, Bolm lgt. & DQ144683 & DQ144707 \\
\hline Metriorrhynchini gen. sp. (3) & dtto & DQ144684 & DQ144708 \\
\hline $\begin{array}{l}\text { Porrostoma rhipidium } \mathrm{W} . \\
\text { M'Leay }\end{array}$ & Australia, Canberra, ACT, 10.xi.2002, S.A. Slipinski lgt. & DQ144678 & DQ144702 \\
\hline Porrostoma sp. & Australia, NSW, 2 km SW Burrill Lake, 17.xi.2002, C. Reid lgt. & DQ144679 & DQ144703 \\
\hline Metriorrhynchus sp. (2) & New Guinea, 23.xii.2000, road Konti Unai to Ambai, 650 m, A. Riedel lgt. & DQ144663 & DQ144689 \\
\hline Metriorrhynchus sp. (1) & dtto & DQ144664 & DQ144690 \\
\hline Metriorrhynchus sp. (3) & New Guinea, Wasior, 150 m, 7.-10.i.2001, A. Riedel lgt. & DQ144669 & DQ144695 \\
\hline Metriorrhynchus sp. (4) & Sulawesi, 20 km NE Sabbang, 400 m, 5.-7.vii.2001, Bolm lgt. & DQ144659 & DQ144685 \\
\hline M. thoracicus (F.) & Sulawesi, Pendolo vill. env., 600 m, 4.-9.vii.1999, Bolm lgt. & DQ144672 & DQ144698 \\
\hline M. lobatus Bocák \& Matsuda & dtto & DQ144662 & DQ144688 \\
\hline Metriorrhynchus sp. (5) & Sulawesi, 20 km NE Sabbang, 400 m, 5.-7.vii.2001, Bolm lgt. & DQ144660 & DQ144686 \\
\hline Metriorrhynchus sp. (5) & dtto & DQ144661 & DQ144687 \\
\hline M. sericans Waterhouse & Laos, Bolawen Plateau, Nong Lom env., 20.iv.1999, E. Jendek lgt. & DQ144673 & DQ144699 \\
\hline M. sericeus Waterhouse & Bali, 12 km NW Bedugul, 950 m, 29.iv.2001, Bolm lgt. & DQ144670 & DQ144696 \\
\hline M. sericeus Waterhouse & dtto & DQ144671 & DQ144697 \\
\hline Metriorrhynchus sp. (6) & Philippines, Luzon, Barling, 2000 m, 9.iv.2000, L. Dembicky lgt. & DQ144676 & DQ144701 \\
\hline Metriorrhynchus sp. (7) & Philippines, Luzon, Patapat Mts, 3.iv.2000, L. Dembicky lgt. & DQ144677 & - \\
\hline Metriorrhynchus sp. (7) & Philippines, Luzon, 12 km N Ocampo, 26. May 1996, Bolm lgt. & DQ144674 & - \\
\hline M. philippinensis Waterhouse & dtto & DQ144675 & DQ144691 \\
\hline M. palawanensis sp. $\mathrm{n}$. & Philippines, Palawan, Rizal, 6.x.2002, J.R. Dacasin lgt. & DQ144665 & DQ144691 \\
\hline M. palawanensis sp. $\mathrm{n}$. & dtto & DQ144666 & DQ144692 \\
\hline M. palawanensis sp. $\mathrm{n}$. & dtto & DQ144667 & DQ144693 \\
\hline M. palawanensis sp. $\mathrm{n}$. & dtto & DQ144668 & DQ144694 \\
\hline
\end{tabular}

phorm method (as used in Vogler et al., 1993). All specimens from the Philippines used for DNA extraction were dry mounted. Two fragments of the mitochondrial genome were PCR-amplified. Approximately 1030 base pairs (bp) of the NADH dehydrogenase subunit 5 gene (ND5) and adjacent tRNA-Phe, tRNA-Glu, tRNA-Ser, and tRNA-Asn were amplified as a 1220 bp fragment by primers OF1 (5'CCTACTCCTGTTTCTGCTTTAGTTCATTC-3') and R6 (5'GAAACGAAAAATCGTATTTAATTTCGACT-3'). The second fragment consisted of $811 \mathrm{bp}$ of cytochrome c oxidase subunit I (COI), tRNA-Leu, and 288 bp of cytochrome c oxidase subunit II (COII) and was amplified using primers JerM (5'-CAACAYYTATTTTGRTTYTTTGG-3') and Marcy (5'TARTTCRTATGWTCAATAYCAYTGRTG-3'). Complementary readings overlapped in the middle by $200-500 \mathrm{bp}$. Primer OF1 for ND5 gene was proposed for Hotaria parvula (Lampyridae) by H. Kusaoke (personal communication), primer JerM is a modified version of the primer C1-J-2183 (Jerry; Simon et al., 1994). Other primers were designed specifically for Lycidae. Thermal cycling conditions were generally $2 \mathrm{~min}$ at $94^{\circ} \mathrm{C}$; $30-60 \mathrm{~s}$ at $94^{\circ} \mathrm{C}, 30-60 \mathrm{~s}$ at $45-52^{\circ} \mathrm{C}, 1-2 \mathrm{~min}$ at $72^{\circ} \mathrm{C}$ (repeated for $30-40$ cycles), and $10 \mathrm{~min}$ at $72^{\circ} \mathrm{C}$. Purified PCR products were sequenced by an $\mathrm{ABI} 377$ automated sequencer using an ABI PRISM Big Dye Terminator Cycle Sequencing Ready Reaction Kit v. 1.1. Difficulties with PCR amplification were encountered in some fragments, especially when DNA was extracted from dry specimens. One species from the Philippines did not yield useful ND5 sequence. Genebank accession numbers are listed in Table 1.

\section{Alignment and phylogenetic analyses}

Protein coding genes exhibited few indels and were aligned by eye. Only the group of tRNAs genes exhibited more indels, and therefore two different settings of alignment parameters were tested to check the impact of alignment on the phylogenetic hypotheses. Clustal X 1.8 was used for alignment with default gap penalties (15 gap opening and 6.66 gap extension for both alignment steps) and lowered penalties (10 and 0.1/0.2 for pairwise and multiple alignment parameters, respectively).

Phylogenetic analysis was performed under maximum parsimony criterion using PAUP*, version $4.0 \mathrm{~b} 10$ (Swofford, 1999). All characters were equally weighted and gaps were treated as missing data. Heuristic searches used 1000 random-additionsequence starting trees for tree-bisection-reconnection (TBR) swapping on best trees. Altogether 500 pseudoreplicates were generated with 100 random taxon additions for bootstrap analysis. All trees were treated as unrooted and the roots were designated subsequently. All branches were collapsed if maximum branch length was zero and no topological constrains were used.

The dataset was additionally analyzed with the Bayesian inference algorithm (MrBayes v. 3.0, Huelsenbeck, 2000), where tree topology and evolutionary model parameters were permuted using a Markov chain Monte Carlo method (MCMC). 
The MCMC was set for independent variability of parameters in individual coding and non-coding genes and general time reversible model was set at the start of the search. Four chains ran simultaneously for 100000 generations, with trees being sampled each 100 generations. The ML score stopped improving after 6-8000 generations, therefore the first 200 trees were discarded and posterior probabilities of the phylogeny were determined from the remaining trees.

\section{RESULTS}

We obtained sequences of two fragments of mtDNA with aligned length 2389 or 2394 characters for the default and lowered gap penalty parameters, respectively. The default parameters produced 1333 constant, 224 variable, parsimony-uninformative, and 832 parsimony informative characters.

Parsimony analysis of the matrix produced by default settings of Clustal X yielded two trees of 3875 steps in length; one of these trees was identical with the strict consensus tree (Fig. 3). The only difference was in the complete dichotomy and/or polytomy in the M. palawanensis clade. The lower gap cost matrix produced trees with identical topology and 3857 steps in length. Bootstrap analysis indicated strong support for most clades hypothesized from default alignment (values given in Fig. 3). The same topology and similar, only slightly higher bootstrap values, were found for clades inferred from data aligned with lower gap costs.

The ND5 and COI/COII fragments were also analyzed separately. We found some topological conflicts between both trees. The tree based on ND5 was similar to those inferred from combined analyses. The monophyletic clade consisting of all species from Sulawesi and the Great Sunda Islands was present in the COI/COII tree, but its bootstrap and jackknife values were low. The Philippine species appeared as sister lineages (Fig. 5).

The tree inferred from the combined matrix using Bayesian analysis had a topology very similar with the tree obtained under the maximum parsimony criterion. The differences were present in the outgroup relationships only. The posterior probabilities of clades were similar to those inferred under the parsimony criterion (Fig. 4).

\section{DISCUSSION}

The monophyly of Metriorrhynchus was supported by all data sets. Only recently Bocák (1998b) separated Porrostoma and Metriorrhynchus on the basis of genitalic characters and this interpretation is supported here by molecular data.

Although there are not enough morphological data available for construction of separate matrix for phylogenetic analysis, we alternatively mapped morphological characters on the tree inferred from molecular data to assess the congruence level. The type species of Metriorrhynchus and related species are characterized by an internal sac with a simple rod-like sclerotized sclerite accompanied by rows of spines and by unique sclerotized vagina (Bocák, 1998b). The species from the Sulawesi Island and Oriental Region have a different male genitalia, with a long or complex sclerite in the internal sac accompanied by considerably reduced number of spines and their vaginae are completely membranous (Figs 28-31). The monophyly of this clade is well supported by high bootstrap values in all analyses (Figs 3-5). The lateral spines of internal sac are present in most Philippine species, although they are reduced to one spine in some of them (Figs 6-27, 32). On the contrary, species known from Sulawesi as well as species from the Greater Sunda Islands do not have these spines. Species from Java and continental Asia show close relationships with M. lobatus and Metriorrhynchus sp. (5); the monophyly of this clade is well supported by high bootstrap values (Figs 3-5).

Two types of female genitalia are found in the studied group of species from Sulawesi and the Oriental Region. One type has long, moderately sclerotized duct of accessory glands, the second one has an accessory gland directly attached to the vagina. The first type is present in the group of Philippine species, in M. thoracicus F. from Sulawesi, and it is known also from species in the Moluccas. The position of these taxa in the tree shows this character to be a synapomorphy of the whole clade. The second type is known from the terminal clade formed by two species from Sulawesi and all species from the Great Sunda Islands and continental Asia (Figs 3-5). In summary morphology appears highly congruent with the phylogenetic hypothesis based on molecular markers.

The Australian origin of the Oriental fauna of Metriorrhynchus was hypothesized by Bocák (2002). The species level phylogeny presented here supports this view. The monophyly of the clade formed by Metriorrhynchus species from Sulawesi, the Philippines and Greater Sundas is well supported and the dispersal route from New Guinea through the Moluccas is expected (Fig. 2). The species from Sulawesi although externally very similar to each other due to mimicry ring evolution (Bocák \& Matsuda, 1998), are a genetically very diverse group (Figs 3-5) and the combined analysis is consistent with two dispersal events for the establishment of the Sulawesi fauna. The four species studied from the Philippines form a well supported clade suggesting a single colonization event. This represents the independent crossing of the Wallace line. Unfortunately, we have not been able to sequence some Philippine species with different genitalia and that could represent another independent clade in the Philippines. There is conflict between signals from ND5 and COI about the sister position of the Philippine clade. The combined analysis and ND5 gene support the sister position of the Philippine clade with one including only part of the Sulawesi species (M. lobatus and Metriorrhynchus sp. 5). Such topology is consistent with a dispersal scenario through northern Sulawesi and the Sulu Islands. The tree inferred from COI sequences shows a deeper rooting of the Philippine clade and therefore the possibility of direct dispersal from the Moluccas. In both cases bootstrap values are quite low and further material is necessary to discriminate alternatives. 

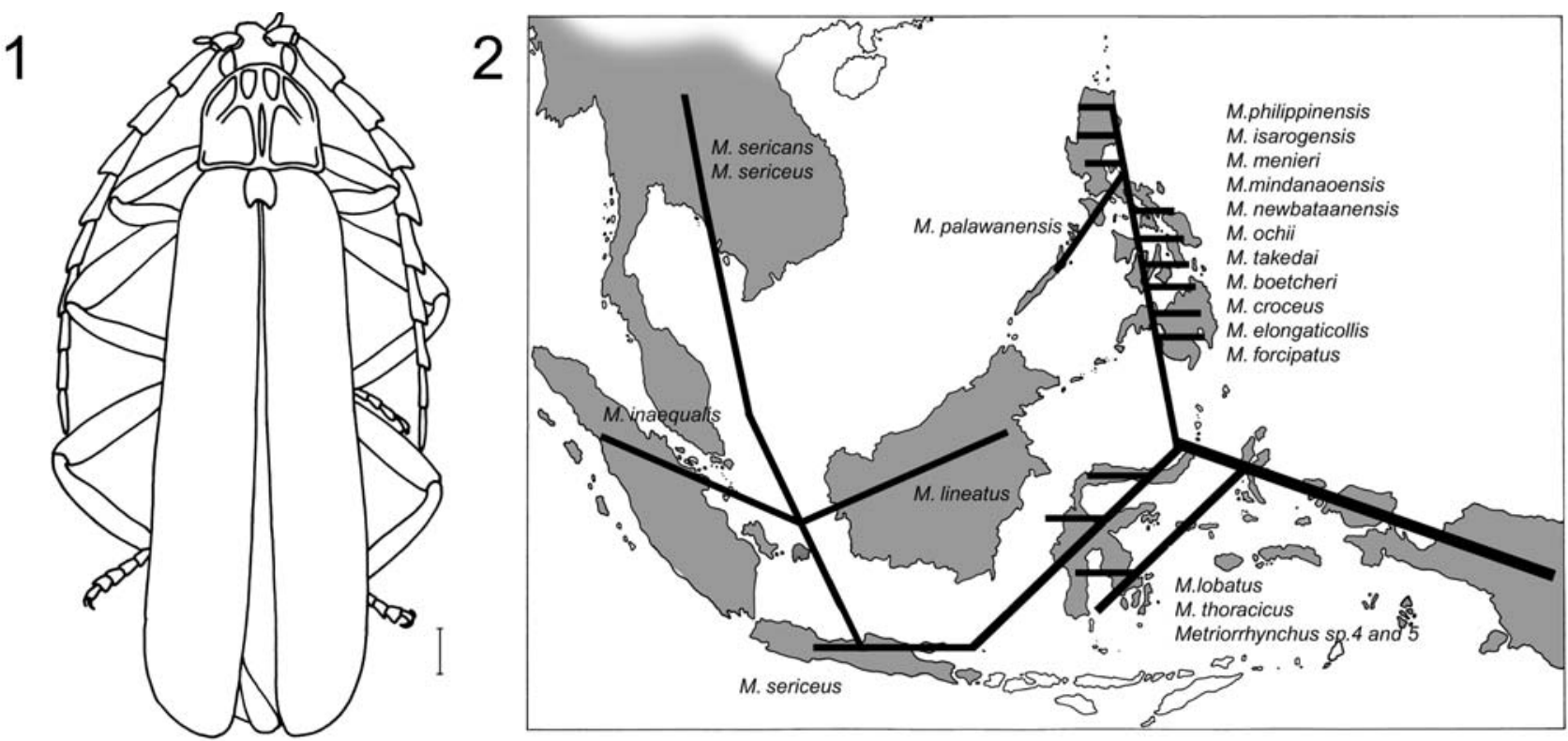

Figs 1-2: 1 - Metriorrhynchus thoracicus F., general appearance; scale $1 \mathrm{~mm} ; 2$ - Relationships and distribution of Metriorrhyncus in the Wallacea and the Oriental Region.

All analyses support the terminal position of the group of species from the Great Sunda Islands and this Sundanese clade is well supported (Figs 3-5). Based on the inferred species level phylogeny we can hypothesize the second dispersal events across the Wallace line from the Moluccas via Sulawesi to Bali and Java (M. sericeus) and further to the north to Sumatra, Borneo, Peninsular Malaysia (M. inaequalis, M. lineatus), Thailand, Laos, Vietnam, Burma and eastern India (M. sericans and $M$. sericeus). The close relationship of these species is well supported by morphology, when only two of them were sequenced in this project.

Metriorrhynchus underwent multiple speciation events in all newly inhabited areas and most species show a high degree of endemism. Four species are known from the Malayan Subregion and at least twelve species from the Philippines. Unlike most groups, the only species in the Palawan Island, Metriorrhynchus palawanensis, is related to the Philippine fauna of the genus. This finding is in contrast with the tectonic history of Palawan, which is of Asian continental origin (Hall \& Blundell, 1996) and the well documented connection of Palawan with Borneo but not with the Philippines during the last glacial maximum $15-20,000$ years BP. The potential factors preventing species dispersal from the Great Sundas are drier climate of Palawan Island and the presence of different mimicry complexes there.

\section{TAXONOMY}

\section{Genus Metriorrhynchus Gemminger \& Harold, 1869}

Type species: Lycus parallelus Guérin Méneville, 1835.

\section{Redescription}

Body small to medium sized, parallel-sided (Fig. 1). Most species brightly colored at least in humeral part of elytra. Head small, partly hidden by pronotum, most spe- cies with short, stout rostrum. Labrum about as long as wide, simply rounded frontally. Mandibles small, slightly curved, without teeth. Antennae serrate in both sexes or flabellate in males of several Papuan species. Maxillary palpi 4-segmented, labial palpi 3-segmented, apical palpomeres parallel-sided to securiform in both palpi. Pronotum wider than long, with seven distinct areoles. Elytra parallel-sided, 3.6-4.9 times longer than width at humeri. Each elytron with four primary costae and five secondary longitudinal costae, which differ slightly in robustness. Transverse costae dense, elytral areolae strongly transverse in most species. Ventral part of body regularly with metallic blue shine. Male genitalia with sclerotized phallobasal membrane, strong straight phallus, which is widened at middle or apical part. Internal sac usually sclerotized, spiral-shaped. Ovipositor small, very slightly sclerotized and firmly attached to terminal abdominal sclerites. Vagina membranous in Oriental species.

Differential diagnosis. The Philippine species are characterized by a short stout rostrum, serrate antennae in both sexes, the characteristic shape of the internal sac in male genitalia and the shape of ovipositor (Figs 28-30). Leptotrichalus Kleine, 1925 is another Oriental genus with rostrum, but it differs in the shortened first elytral costa and the simple pattern of pronotal costae, which form a single central areola.

\section{Ecology}

Larvae live under bark and in rotten wood and a development up to four years is expected. Sometimes the larvae are present on the surface of trunks and many of them are brightly colored (Bocák \& Matsuda, 2003). Unlike most oriental lycids, they are able to colonize also periodically dried pieces of wood in sunny places. Adults are free living, sitting on leaves or visiting flowers. They 


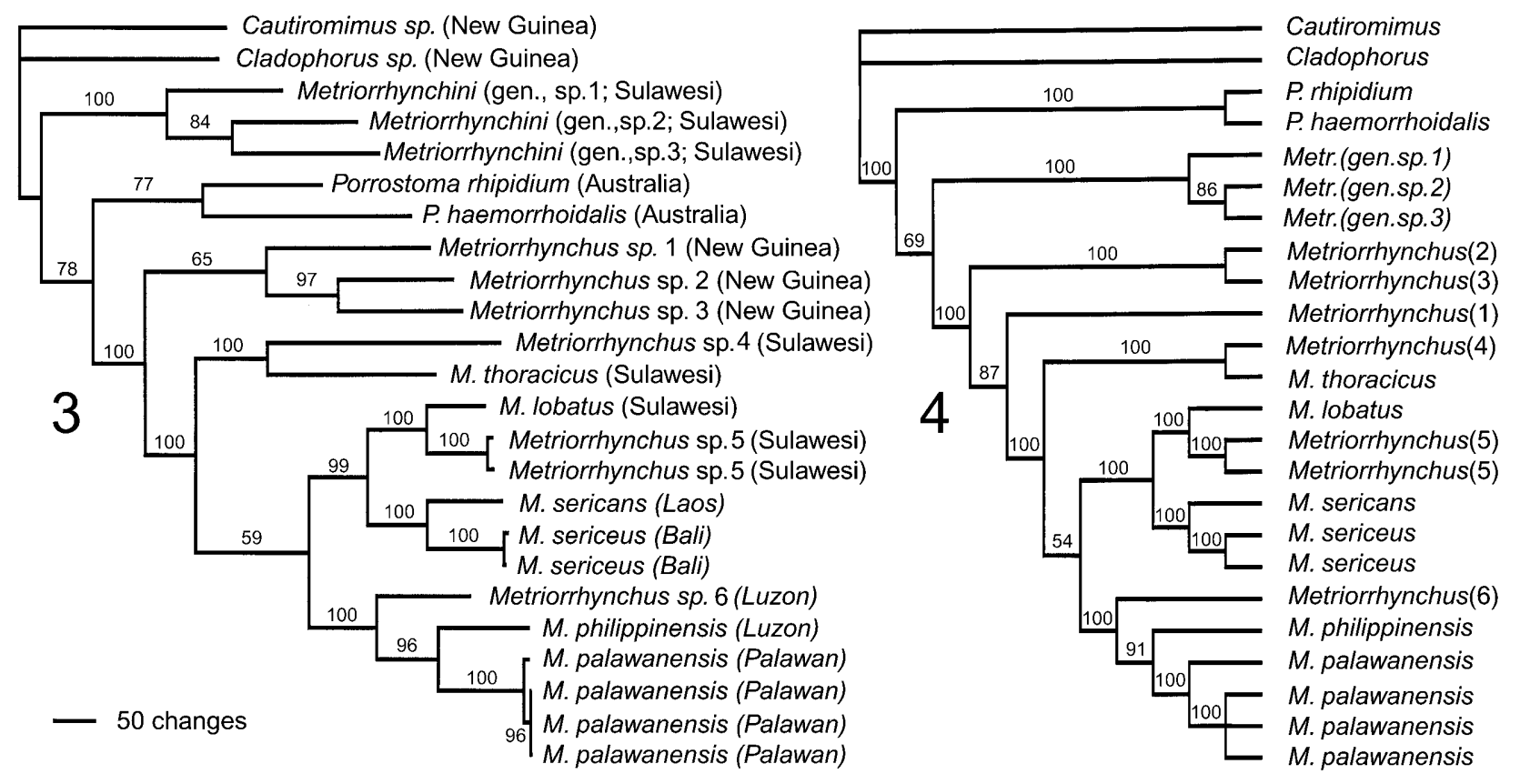

Figs 3-4: 3 - Phylogram of Metriorrhynchus inferred from the maximum parsimony analysis of ND5 and COI/COII genes; 4 Cladogram of Metriorrhynchus inferred using Bayesian analysis of ND5 and COI/COII genes. Numbers above branches indicate bootstrap and posterior probability values $(\times 100)$, respectively.

occur usually together with Leptotrichalus species when visiting flowers and resemble them in general appearance.

\section{Metriorrhynchus boettcheri Kleine, 1926}

Metriorrhynchus boettcheri Kleine, 1926: 80.

\section{Redescription}

Male. Body medium-sized to large, black. Pro- and mesothorax sometimes brown; metathorax and abdomen always black with metallic blue shine. Pronotum and humeral third of elytra orange yellow; posterior part of elytra black. Head small, with short rostrum. Eye diameter 1.17 times frontal distance. Pronotum 1.09 times longer than width at base, its surface mat. Scutellum orange with black patch at middle. Elytra slender, transition from bright to black part gradual. Phallus stout, curved in middle part and with conspicuous teeth at apex. Sclerite in internal sac short, simply curved, membrane with several spines laterally (Figs 6-7). Female. Body larger, eyes smaller, their diameter 0.75 times frontal distance. Ovipositor as in Fig. 28.

Differential diagnosis. $M$. boettcheri belongs to the group of the Philippine species with bicolored elytra, which includes additionally $M$. forcipatus and $M$. croceus. The male genitalia show close relationships with $M$. forcipatus. The shape of phallus provides clear distinguishing characters between these two species (Figs 6-9).

Measurements. BL $16.7 \mathrm{~mm}$, WH $3.70 \mathrm{~mm}$, PL $2.54 \mathrm{~mm}$, PW $2.78 \mathrm{~mm}$, Edist $0.84 \mathrm{~mm}$, Ediam $0.98 \mathrm{~mm}$

Type material. Female, holotype, (No. 679), Boettcher, Luzon; Prov.: Nueva Vizcaya, male, allotype (No. 680), same locality data, paratype (No. 681), same locality data (all in ZMPA).

Distribution. Philippines, Luzon Is., only known from the type locality.
Remarks. The specimens at Kleine's collection are designated as holotype (No. 679), allotype (No. 680) and paratype (No. 681). None of these specimens was dissected by Kleine and the type designation labels were written by Mroczkowski (Mroczkowski, 1959). There is no explicit mention to holotype and paratypes in the original description and the designations made by Mroczkowski are invalid, so that all specimens should be considered syntypes. As the identity of the species is clear, we do not designate the lectotype here.

\section{Metriorrhynchus croceus Kleine, 1926}

Metriorrhynchus croceus Kleine, 1926: 79.

\section{Description}

Male. Body small, head, metathorax and abdomen black; pro- and mesothorax light brown to black; pronotum, scutellum and basal half to two thirds of elytra orange yellow, posterior part of elytra black. Head with short rostrum, eyes small, their diameter 0.87 times frontal distance. Pronotum 1.10 times wider at base than length at midline. Elytra 3.5 longer than combined width at humeri, elytral cells tiny, only slightly transverse, transition between bright and black parts of elytra very gradual. Male genitalia with slender, straight phallus; only minute dent in apical part, without any processes (Figs 11-12). Female not available.

Differential diagnosis. $M$. croceus differs from other species with bicoloured elytra in the shape of male genitalia (Figs 11-12) and considerably smaller eyes. The genitalia resemble those of $M$. elongaticollis, which belongs to another color pattern.

Measurements. BL $9.1 \mathrm{~mm}$, WH $2.24 \mathrm{~mm}$, PW $1.78 \mathrm{~mm}$, PL $1.62 \mathrm{~mm}$, Edist $0.63 \mathrm{~mm}$, Ediam $0.55 \mathrm{~mm}$. 


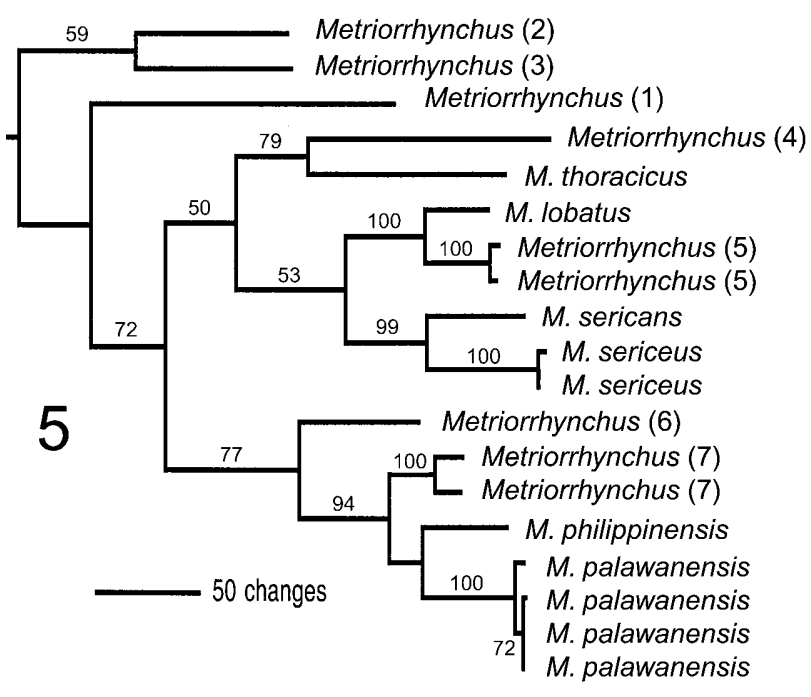

Fig. 5. Phylogram of Metriorrhyncus inferred from the maximum parsimony analysis of COI/COII genes. Numbers above branches indicate bootstrap values. The outgroup taxa are omitted.

Type material. Male, holotype (No. 683), Butuan, Mindanao, Baker; male, paratype, (No. 684), Dapitan, Mindanao, Baker; male, paratype, (No. 685), Surigao, Mindanao, Baker; male, paratype, (No. 686), Kolambugan, Mindanao, Baker (all in ZMPA). Other material examined. Male, Philippines (MNHN); male, Mindanao Is., Surigao del Sur, Castillo, 12-15.iv.1983, N. Nishikawa lgt. (KMTC).

Distribution. Philippines: Mindanao.

Remarks. Kleine (1926) stated that both males and females are present in the type series, but only four males were found in his collection. The status of types was designated by Mroczkowski (1959) and is invalid (cf. $M$. boettcheri above).

\section{Metriorrhynchus elongaticollis Pic, 1925}

Metriorrhynchus elongaticollis Pic, 1925: 9.

\section{Description}

Male. Body large, black, only pronotum, scutellum and elytra yellow. Head small, with short stout rostrum, eye distance 1.16 times eye diameter. Pronotum 1.04 times wider at base than length at midline, surface shining, with very fine microstructure. Elytra slender, parallel-sided, elytral cells regular, only very slightly transverse. Male genitalia with robust straight phallus. Spiral sclerite of internal sac long, exposed (Fig. 10). Female unknown.

Differential diagnosis. $M$. elongaticollis is externally similar to other yellow species and can be identified only by characters in male genitalia (Fig. 10).

Measurements. BL $9.2 \mathrm{~mm}$, WH $2.18 \mathrm{~mm}$, PL $1.64 \mathrm{~mm}$, PW $1.73 \mathrm{~mm}$, Edist $0.67 \mathrm{~mm}$, Ediam $0.58 \mathrm{~mm}$.

Type material. Male, holotype of $M$. elongaticollis, Mindanao, Momungan (MNHN). Other material examined. Male, Mt. Apo, Mindanao Is., Philippines, 20-30.iii.1977, leg. R.M. Lumawig (KMTC).

Distribution. Philippines: Mindanao.
Metriorrhynchus forcipatus Kleine, 1926

Metriorrhynchus forcipatus Kleine, 1926: 79.

\section{Redescription}

Male. Body medium-sized, yellow; only head, abdomen, apical third of elytra and legs except trochanters black. Head with short, slender rostrum. Eyes large, hemispherically prominent, their diameter 1.47 times interocular distance. Pronotum slightly shining, 1.20 times wider at base than length at midline. Elytra slender, slightly widened backwards, elytral cells irregular, slightly transverse, border between light and black portions clear. Phallus slender, with curved, slender apical process; internal sac extensive, with small sclerite and group of spines (Figs 8-9). Female unknown.

Differential diagnosis. M. forcipatus belongs to the group of species with bicolored elytra. Male genitalia show very close relationships with $M$. boettcheri. $M$. forcipatus has a considerably slenderer phallus and a smaller sclerite in the internal sac (Figs 6-9).

Measurements. BL $13.2 \mathrm{~mm}$, WH $2.76 \mathrm{~mm}$, PL $1.86 \mathrm{~mm}$, PW $2.24 \mathrm{~mm}$, Edist $0.57 \mathrm{~mm}$, Ediam $0.84 \mathrm{~mm}$.

Type material. Male, holotype (No. 698), Baguio, Benguet, Baker (ZMPA). Other material examined. Female, same locality data (ZMPA); female, Luzon Is., Baguio, Benguet, Mt. Prov., 10.vi.1990, I.O. Lumawig lgt.; female, Negros Is., Mt. Canlaon, 15.ix.1990, D. Mohagan lgt. (KMTC).

Distribution. Philippines: Luzon, Negros.

Remark. M. forcipatus resembles in general appearance very common species of the genus Leptotrichalus (Metriorrhynchini, Trichalina).

\section{Metriorrhynchus isarogensis sp. $\mathbf{n}$. Description}

Male. Body small, slender, black; only pro- and mesothorax brown. Pronotum generally dark but at least very basal part of pronotal costae are brown in all available specimens. Head small, with short, stout rostrum. Eyes small, their frontal distance 1.37 times eye diameter. Pronotum 1.1 wider than long, mat with apparent fine microstructure at middle of disc and rough structure at frontal and lateral margins. Elytra slender, with irregular, only slightly transverse elytral cells. Phallus slender, slightly asymmetrical at apex, with spiral sclerite of internal sac and groups of spines laterally (Figs 13-14). Female unknown.

Differential diagnosis. $M$. isarogensis is the only Philippine species with black pronotum and elytra and it is a species with exceptionally small body in the genus Metriorrhynchus. Male genitalia show relationships with $M$. palawanensis.

Measurements. Holotype, BL $8.3 \mathrm{~mm}$, WH $1.80 \mathrm{~mm}$, PW $1.44 \mathrm{~mm}$, PL $1.30 \mathrm{~mm}$, Edist $0.63 \mathrm{~mm}$, Ediam $0.46 \mathrm{~mm}$.

Type material. Male, holotype, Luzon, Camarines Sur, 12 km N of Ocampo, Mt. Isarog, 25.-27.v.1996, Bolm lgt. (NHMB), 3 males, paratypes, same locality data (LMBC).

Etymology. The specific name refers to the type locality of the species.

Distribution. Philippines: Luzon (Camarines Sur). Only known from the type locality. 

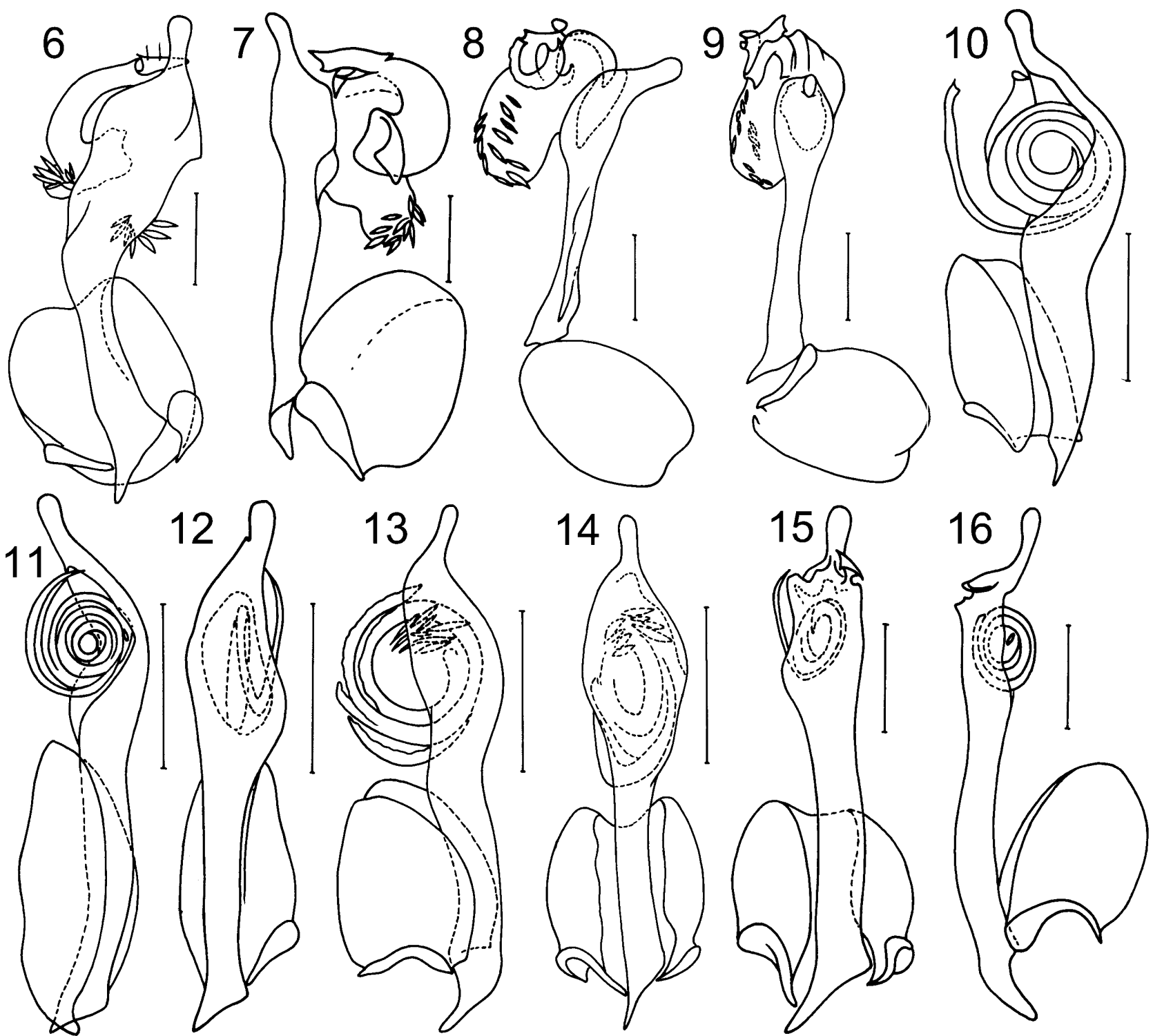

Figs 6-16: Male genitalia. 6,7-Metriorrhynchus boettcheri; 8, 9 - M. forcipatus; 10 - M. elongaticollis; 11, 12 - M. croceus, 13, 14 - M. isarogensis; 15, $16-$ M. mindanaoensis. Scales $0.5 \mathrm{~mm}$.

Remarks. M. isarogensis occurs on flowers together with dark coloured Leptotrichalus species, which are very similar also in body size and shape. The possibility of coevolutionary mimicry is supported by the suppressed light coloration of pronotum and pro- and mesothorax.

\section{Metriorrhynchus menieri sp. $\mathrm{n}$.}

\section{Description}

Male. Body medium-sized, slender, black; only pronotum, scutellum and elytra yellow, black body parts with apparent metallic blue shine. Head small, rostrum short, slightly wider than long. Eyes small, their frontal distance 1.40 times eye diameter. Pronotum as long as width at base, mat with apparent fine microstructure at middle of disc and rough structure at frontal and lateral margins. Elytra slender, with regular, tiny, only slightly transverse elytral cells. Phallus stout, widest in apical third, with very long spiral sclerite of internal sac. Apex flattened, with asymmetrical process (Figs 23-24). Female unknown.

Differential diagnosis. $M$. menieri reminds $M$. ochii by the shape of phallus, especially its apex, and the relatively small eyes. They differ in the shape of phallus in lateral view (Figs 23-26).

Measurements. BL $13.2 \mathrm{~mm}$, WH $2.52 \mathrm{~mm}$, PL $2.02 \mathrm{~mm}$, PW $2.04 \mathrm{~mm}$, Edist $0.81 \mathrm{~mm}$, Ediam $0.58 \mathrm{~mm}$.

Type material. Holotype. Male, Luzon Is., nr. Baguio, Asin Hot Spring, Benguet Mt. Prov., 22.iii.1978, K. Matsuda lgt. (EIHU); paratype, male, Negros Is., Mt. Canlaon, 15.ix.1990, D. Mohagan lgt. (KMTC)

Etymology. The name "menieri" is a patronym in honour of J.J. Menier (Paris).

Distribution. Philippines: Luzon, Negros. 

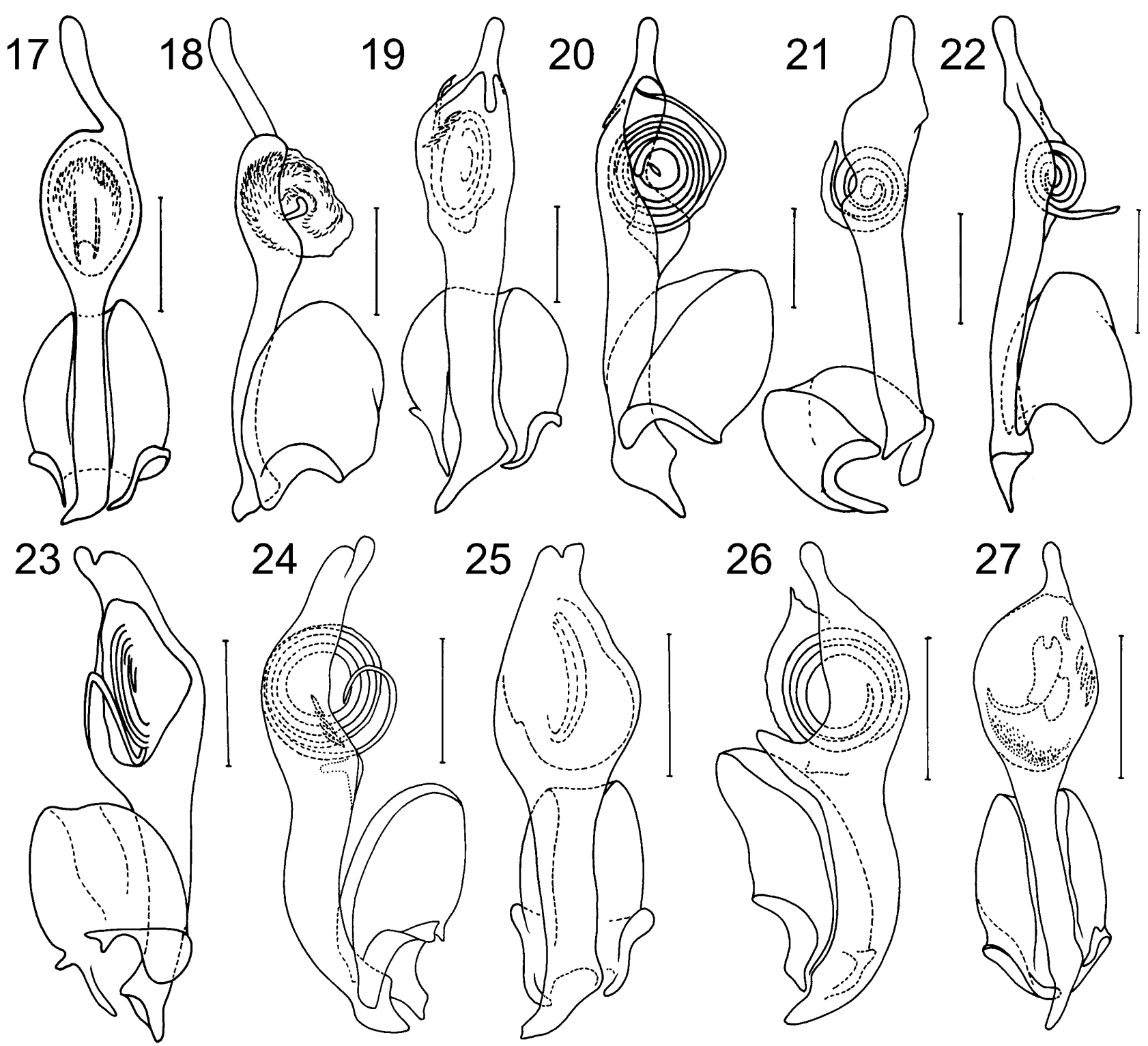

Figs 17-27: Male genitalia. 17, 18 - Metriorrhynchus newbataanensis; 19, 20 - M. palawanensis; 21, 22 - M. philippinensis; 23, 24 - M. menieri; 25, 26 - M. ochii; 27 - M. takedai. Scales $0.5 \mathrm{~mm}$.

\section{Metriorrhynchus mindanaoensis sp. $\mathbf{n}$.}

\section{Description}

Male. Body medium-sized to large, black with apparent metallic blue shine; pronotum, scutellum, and elytra yellow; pro- and mesothorax seldom light brown. Head with small, stout rostrum. Eyes small, their diameter 0.74 times frontal distance. Pronotum mat, with fine microstructure, 1.05 wider at base than length at midline; pronotal costae strong, well developed. Elytra slender, parallel-sided, elytral cells regular, small, strongly transverse. Phallus slender, straight, slightly asymmetrical at apex, with complex processes and depressions (Figs 15-16). Female larger.

Differential diagnosis. $M$. mindanaoensis belongs to a group of very similar species with large body and yellow pronotum and elytra. It differs in the shape of male genitalia and internal sac. The closest species is M. palawanensis. Both species share the presence of a process in the apical part of the phallus (Figs 15-16, 19-20). Females cannot be identified neither by external nor genitalic characters and they are identified in the type series only due to the association with males in the field.

Measurements. BL $16.7 \mathrm{~mm}$, WH $3.95 \mathrm{~mm}$, PL $3.18 \mathrm{~mm}$, PW $3.34 \mathrm{~mm}$, Edist $1.06 \mathrm{~mm}$, Ediam $0.78 \mathrm{~mm}$.

Type material. Male, holotype, Mt. Apo, Mindanao Is., Philippines, 20.-31.iii.1977, leg. R.M. Lumawig (EIHU). Paratypes. 103 males, 83 females, same locality data (KMTC, LMBC). Male, Mindanao Is., Mt. Kitanglad, 25.v.-8.vi.1990, D. Mohagan lgt.; male, Mindanao Is., Surigao del Sur, Castillo, 12-15.iv.1983, N. Nishikawa lgt.; 3 males, Leyte Is., Babatugon, 7-14.viii.1982, S. Takeda lgt.; 5 males, Luzon Is., nr. Lucena, Kinabuhayan, 8.iv.1989, N. Monreal lgt. (KMTC, LMBC).

Etymology. The specific name refers to the type locality of the species.

Distribution. Philippines: Mindanao, Leyte. Luzon. 

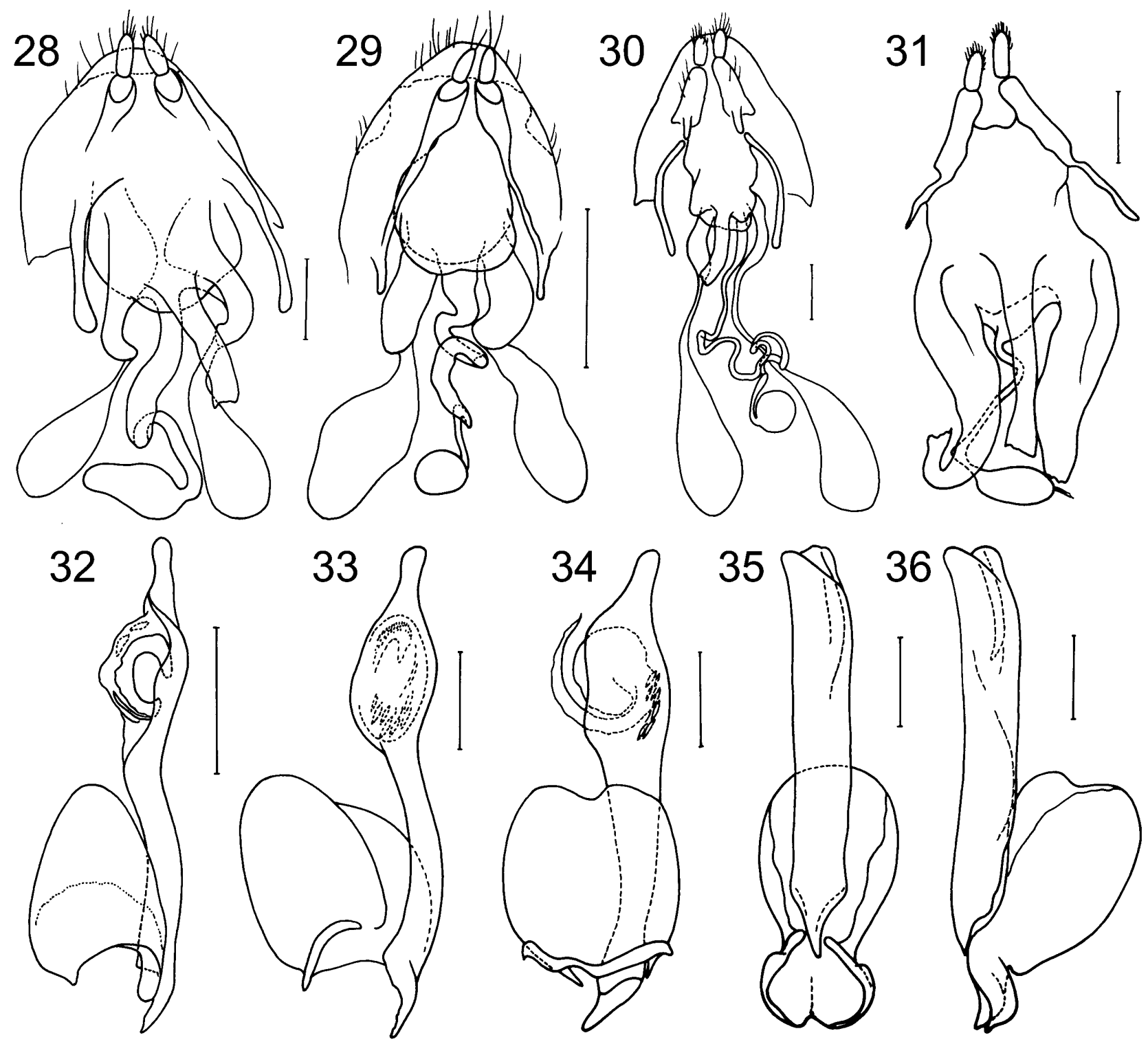

Figs 28-36. 28-31. Female genitalia. 28 - M. boettcheri; 29 - M. forcipatus; 30 - M. philippinensis; 31 - M. cribripennis. 32-36. Male genitalia. 32 - M. takedai; 33, 34 - M. yoshioi; 35, 36-M. longissimus. Scales 0.5 mm.

\section{Metriorrhynchus newbataanensis sp. $\mathrm{n}$.}

\section{Description}

Male. Body medium-sized, head, metathorax, abdomen and legs except trochanters black, pro- and mesothorax, pronotum, scutellum and elytra yellow. Head small, with short stout rostrum. Eyes large, hemispherically prominent, their diameter 1.26 times frontal distance. Pronotum mat, with rough structure at frontal and lateral margins, 1.06 times wider at base than length at midline. Elytra slender, parallel-sided, elytral cells regular, slightly transverse. Phallus widest in apical third, with asymmetrical slender apical process, internal sac with dense tinny setae. Female unknown.

Differential diagnosis. $M$. newbataanensis belongs to the group of yellow species and can be identified only by the shape of male genitalia and size of male eyes. Genitalia are characterized by the long apical process of phallus and setose internal sac (Figs 17-18) and they resemble those of $M$. takedai sp $\mathrm{n}$. in the shape of phallus.

Measurements. BL $12.7 \mathrm{~mm}$, WH $2.52 \mathrm{~mm}$, PL $1.96 \mathrm{~mm}$, PW $2.08 \mathrm{~mm}$, Edist $0.68 \mathrm{~mm}$, Ediam $0.86 \mathrm{~mm}$.

Type material. Male, holotype, Mindanao, Davao Prov., 25 km W New Bataan, 1200 m, 20.-22.v.1996, Bolm lgt. (NHMB).

Etymology. The specific name refers to the type locality of the species.

Distribution. Philippines: Mindanao.

\section{Metriorrhynchus ochii sp. n. \\ Description}

Male. Body small, slender, black; pro- and mesothorax brown, pronotum, scutellum, and elytra yellow. Head small, with short, stout rostrum. Eyes small, their frontal distance 1.25 times eye diameter. Pronotum only slightly wider than long, mat, with apparent fine microstructure at middle of disc and slightly rougher structure at frontal margin. Elytra slender, with regular, only slightly trans- 
verse elytral cells. Phallus stout, widest in apical third, slightly asymmetrical at apex, internal sac with long, spiral sclerite (Figs 25-26). Female unknown.

Differential diagnosis. $M$. ochii is similar to M. menieri and differs in the slightly larger eyes and the shape of phallus in the lateral view (Figs 23-26).

Measurements. BL $9.9 \mathrm{~mm}$, WH $2.32 \mathrm{~mm}$, PL $1.92 \mathrm{~mm}$, PW $1.86 \mathrm{~mm}$, ED $0.74 \mathrm{~mm}$, Ediam $0.59 \mathrm{~mm}$.

Type material. Holotype. Male, Sibuyan Is., iii-v.1982, P. Ryano lgt. (EIHU).

Etymology. The name "ochii" is a patronym in honour of $\mathrm{Mr}$. Teruo Ochi (Osaka).

Distribution. Philippines: Sibuyan.

\section{Metriorrhynchus palawanensis sp. $\mathbf{n}$. Description}

Male. Body medium-sized, slender, parallel-sided; body black, with light blue metallic shine, only pronotum, scutellum, and elytra orange yellow. Head small, with short rostrum, frontal distance between eyes 1.23 times eye diameter. Antennomeres 3-10 acutely serrate. Pronotum flat, slightly wider at base than length at midline, mat, with strong pronotal costae forming seven areolae, with row of punctures at lateral margins. Scutellum almost parallel-sided, flat, acutely emarginate at apex. Elytra parallel-sided, primary costae strong, secondary and transverse costae very weak. Areoles strongly transverse. Phallus stout, widest at apical fifth, narrowed to apex, with process ventrally (Fig. 19-20). Female. Vagina with slender, partly sclerotized ducts to lateral accessory glands.

Differential diagnosis. The only species of Metriorrhynchus in the Palawan Island. Male genitalia show close relationships to $M$. mindanaoensis, which differs in the shape of phallus (Figs 15-16, 19-20).

Measurements. BL $13.8 \mathrm{~mm}$, WH $3.04 \mathrm{~mm}$, PW $2.72 \mathrm{~mm}$, PL $2.46 \mathrm{~mm}$, Edist $0.65 \mathrm{~mm}$, Ediam $0.64 \mathrm{~mm}$.

Type material. Holotype. Male, Philippines, Palawan Is., Rizal, 5.xii.2002, J.R. Dacasin lgt. (EIHU). Paratypes. Male, N Luzon, Zambales pr., Zambales mts., High Peak, west side, 850 m, 15.28 N 120.03-06 E, L. Dembicky leg., 18.iii.2000 (LMBC); 2 females, Palawan, Tanabank river, 20.xii.1991, Bolm lgt. (LMBC); female, Philippines, Palawan, Puerto Princessa env., 300-500 m, ii.1999, local collector (LMBC); female, Philippines, Palawan central, Sabang, 50-100 m, 30.xi.1995, J. Kodada lgt. (LMBC); female, Palawan centr., Lion's cave nr Cabayuga, 1.xii.1995, J. Kodada lgt. (LMBC); female, Palawan Is., Langogan, 10.iv.1976, H. Detani lgt. (KMTC); 36 males, 15 females, Palawan Is., Brooke's Point, J.R. Dacasin lgt., 8.xii.2002, 18.v.2003, 24.vii.2003, 8.-14.vii.2003, 20.ix.2003, 2.x.2003, 16.x.2003, 20.x.2003, 28.x.2003 (KMTC, LMBC); 4 males, 22 females, Palawan Is., Rio Tuba, J.R. Dacasin lgt., 1.vii.2003, 19.vii.2003, 30.vii.2003, 1.viii.2003 (KMTC, LMBC); 14 males, 27 females, Palawan Is., Rizal, Balete, 900 m, J.R. Dacasin lgt., 5.-12.v.2000, 21.ii.2002, 27.ii.2002, 5.iii.2002， 8.viii.2002，9.ix.2002，20.ix.2002， 3.x.2002, 6.x.2002, 10.x.2002, 5.xii.2002 (KMTC, LMBC); 106 males, 55 females, Palawan Is., Rizal, Punta Baja, 800 m, J.R. Dacasin lgt. 14.i.2003, 18.i.2003, 26.i.2003, 5.ii.2003, 3.iii.2003, 6.iii.2003, 16.iii.2003, 18.iii.2003, 22.iii.2003, 24.iii.2003, 2.vi.2003, 4.vii.2003, 2.ix.2003, 18.iii.2004, 14.iv.2004, J.R. Dacasin lgt. (KMTC, LMBC); 3 male, 5 females, Palawan Is., Rizal,
Quezon, 8.xi.2003, J.R. Dacasin lgt. (KMTC, LMBC); 11 males, 7 females, Palawan Is., Olanguan, 1-9.iv.2004, J.R. Dacasin lgt. (KMTC, LMBC); 2 males, 9 females, Palawan Is., Irawan, 28.ii.2003, J.R. Dacasin lgt. (KMTC, LMBC); male, Palawan Is., Bataraza, 5.ii.2003, J.R. Dacasin lgt.; 2 males, same locality, 6.ix.2003, J.R. Dacasin lgt. (KMTC, LMBC). 4 males, Philippines, C Luzon, Kinabuhayan, nr. Lucena, 8.iv.1989, N. Monreal lgt. (KMTC, LMBC).

Etymology. The specific name refers to the type locality of the species.

Distribution. Philippines: Palawan, Luzon (Zambales Prov.).

Metriorrhynchus philippinensis Waterhouse, 1879

Metriorrhynchus philippinensis Waterhouse, 1879: 52.

\section{Redescription}

Male. Body medium-sized to large, black; head, metathorax and legs black with apparent metallic shine; proand mesothorax, pronotum, scutellum and elytra yellow. Head small, with short stout rostrum. Eyes small, frontal distance between eyes 1.21 times eye diameter. Pronotum 1.1 times wider than length at midline. Elytra parallelsided, slender, elytral cells tiny, regular, strongly transverse. Phallus slender (Figs 21-22). Female genitalia as in Fig. 30.

Differential diagnosis. $M$. philippinensis belongs to the group of yellow species and can be identified only by characters in the male genitalia and the size of male eyes. Phallus slender, apex asymmetrical with lateral process, spiral sclerite of internal sac smaller than in related species (Figs 21-22).

Measurements. Holotype. BL $16.5 \mathrm{~mm}$, WH $4.05 \mathrm{~mm}$, PW $3.30 \mathrm{~mm}$, PL $3.00 \mathrm{~mm}$, Edist $1.02 \mathrm{~mm}$, Ediam $0.84 \mathrm{~mm}$.

Type material. Male, holotype of M. philippinensis, Philipp. Is $(\mathrm{BMNH})$. Other material examined. Four males, two females, Luzon, Camarines Sur, $12 \mathrm{~km} \mathrm{~N}$ of Ocampo, Mt. Isarog, 25.-27.v.1996, Bolm lgt. (LMBC); male, Luzon Is., Bicol National Park, 5-8.ii.1985, A. Kato lgt.; 8 males, Luzon Is., nr. Lucena, Kinabuhayan, 8.iv.1989, N. Monreal lgt.; male, Summit, Catanduanes Is., 23-24.iii.1983, N. Nishikawa lgt.; male, Negros Is., Mt. Canlaon, 15.ix.1990, D. Mohagan lgt.; male, Leyte Is., Lake Imeluda, 10.viii.1982, S. Takeda lgt.; Mindanao Is., 2 males, Mt. Kitanglad, 1-10.viii.1990, D. Mohagan lgt. (KMTC).

Distribution. Philippines: Luzon, Leyte, Negros, Mindanao.

Remark. Kleine (1926) mentioned several thousands of specimens, which he studied. They are not deposited in his collection and as he did not dissect genitalia of more specimens he did not find the presence of additional species in the Philippines. He reported this species also from Palawan, but confirmed records are known only from the main Philippine Islands.

\section{Metriorrhynchus takedai sp. $\mathbf{n}$. \\ Description}

Male. Body small, slender, black; pro- and mesothorax, pronotum, scutellum and elytra bright yellow. Head small, with short, stout rostrum. Eyes large, their frontal distance 0.79 times eye diameter. Pronotum as wide at base as long along midline, mat with fine microstructure in the middle of the disc and slightly rougher structure at middle of frontal margin. Elytra slender, elytral cells 
regular, tiny, only slightly transverse. Phallus very slender in basal half, strongly widened in apical third, asymmetrical apically, with spiral sclerite of internal sac and groups of spines laterally (Figs 27, 32). Female unknown.

Differential diagnosis. Phallus reminds that of $M$. newbataanensis but differs in the shape of the apical process (Figs 27, 32). Both species share also large eyes in males and are probably closely related.

Measurements. BL $10.0 \mathrm{~mm}$, WH $2.18 \mathrm{~mm}$, PL $1.72 \mathrm{~mm}$, PW $1.70 \mathrm{~mm}$, Edist $0.57 \mathrm{~mm}$, Ediam $0.72 \mathrm{~mm}$.

Type material. Holotype. Male, Leyte Is., Lake Imeluda, 10.viii.1982, S. Takeda lgt. (EIHU).

Etymology. The name "takedai" is a patronym in honour of Mr. S. Takeda.

Distribution. Philippines: Leyte.

\section{A key to identification of Metriorrhynchus species from the Philippines}

1 Elytra completely yellow or orange yellow ......... 5

- Elytra black at least at apex. ................ 2

2 Elytra completely black, body small, male genitalia as in Figs $13-14 \ldots \ldots \ldots \ldots \ldots \ldots$. isarogensis sp. n.

- Elytra bright yellow or orange in humeral part ........ 3

3 Male eye diameter larger than interocular distance ..... . 4

- Male eye diameter smaller than interocular distance, phallus slender with long, spiral sclerite of internal sac (Figs 11-12)

4 Male eye diameter less than 1.25 interocular distance, phallus curved, sclerite of internal sac large (Figs 6-7) ....

M. boettcheri Kleine

- Male eye diameter more than 1.25 interocular distance, phallus straight, only apex slightly curved, sclerite of internal sac small (Figs 8-9)......... M. forcipatus Kleine

5 Male eye diameter larger than their interocular distance . . 6

- Male eye diameter smaller than their interocular distance . 7

6 Male genitalia as in Figs 27, $32 \ldots \ldots \ldots$. . takedai sp. n.

- Male genitalia as in Figs 17-18 ... M. newbataanensis sp. n

7 Phallus slender, almost parallel-sided in whole length, sclerite of internal sac smaller (Figs 15-16, 21-22). . . . 8 8

- Phallus widened in apical half, sclerite of internal sac large,

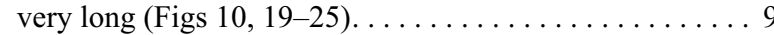

8 Complex process and depressions in apex of phallus (Figs 15-16).................. Mindanaoensis sp. $\mathrm{n}$.

- Only lateral triangular process present in the apical part of phallus (Figs $21-22$ )....... M. philippinensis Waterhouse

9 Apex of phallus flattened, with lateral, finger-like process (Figs $23-25) \ldots \ldots \ldots \ldots \ldots \ldots \ldots \ldots \ldots \ldots \ldots \ldots \ldots \ldots$

- Apex of phallus simple, finger shaped (Figs 10, 19-20) . 11

10 Ventral part of phallus with strong process in middle of its length observed in lateral view (Fig. 26) .... M. ochii sp. n.

- Ventral part of phallus without any process, outline simple, bow-shaped (Fig. 23-24). . . . . . . . . . . M. menieri sp. n.

11 Apical part of phallus with slender dorsal process (Figs 19-20).................... M. palawanensis $\mathrm{sp.} \mathrm{n}$

- Apical part of phallus without any dorsal process (Fig. 10) . ............................. elongaticollis Pic

\section{Species excluded from the genus Metriorrhynchus}

Leptotrichalus pallidus (Dalman in Schoenherr, 1818), comb. $n$.

Lycus pallidus Dalman in Schoenherr, 1818: 31.

Metriorrhynchus pallidus (Dalman in Schoenherr, 1818): Kleine: 1933: 82.
Type material. Female, holotype, Ins. Solo, Mar. Austr., D. Osbeck, (NHRS).

Remark. Kleine (1933) classified Lycus pallidus in Metriorrhynchus, but it belongs to the genus Leptotrichalus Kleine, 1925.

\section{Metriorrhynchus species from the regions adjacent to the Philippine Islands}

Metriorrhynchus longissimus (Pic, 1922), comb. n.

Xylobanus longissimus Pic, 1922: 16.

\section{Redescription}

Male. Body large, very slender, black; pronotum, scutellum and elytra yellow. Head small, without rostrum. Between eyes distance 1.47 times maximum eye diameter. Antennae serrate, reaching middle of elytra length. Both palpi with wide, securiform apical palpomere. Pronotum as long as wide, rounded anteriorly, parallel-sided laterally. Elytra very slender, 4.8 times longer than combined width at humeri. Only four longitudinal costae present on each elytron. Elytral cells strongly transverse, mostly regular, seldom forming an " $\mathrm{x}$ " pattern. Male genitalia with simple parallel-sided phallus (Figs 35-36). Female genitalia weakly sclerotized, slender, with very long spermaduct.

Differential diagnosis. $M$. longissimus is at present the only species in the genus without secondary elytral costae. The phallus of this species is very characteristic (Figs 35-36).

Measurements. Holotype, female. BL $13.6 \mathrm{~mm}$, WH 2.72 $\mathrm{mm}$, PW $2.08 \mathrm{~mm}$, PL $2.08 \mathrm{~mm}$. Male. Edist $0.89 \mathrm{~mm}$, Ediam $0.61 \mathrm{~mm}$.

Type material. Male, holotype, Nord Celebes, Toli-Toli, xi.-xii.1895, H. Fruhstorfer (MNHN). Other material examined. Male, same locality data (MNHN); male, female, Tjamba, Zuid Celebes, Doherty, viii, ix (BMNH).

Distribution. Sulawesi.

Remark. Pic (1922) classified this species in Xylobanus on the basis of the structure of elytral costae. The structure of elytral costae was used for long time as a very convenient character in the lycid classification, but similar structures evolved many times in different clades and they cannot be used in a classification based on phylogeny. Both male and female genitalia show close relationships with other species of Metriorrhynchus in the area. Female genitalia have long, weakly sclerotized basal parts of accessory glands, which are known in all species from the Philippines and M. thoracicus Fabricius, 1801 from Sulawesi (Figs 28-30). Male genitalia are similar to those of one unidentified species from Sulawesi (cf. Figs 35-36 and Fig. 12 in Bocák \& Matsuda, 1998). These characters support the association of $M$. longissimus with the Metriorrhynchus clade from Moluccas, Sulawesi and Philippines.

\section{Metriorrhynchus yoshioi sp. n. \\ Description}

Male. Body medium sized, head, metathorax and abdomen black, pro- and mesothorax, pronotum, scutellum and elytra yellow. Head small, with short rostrum, 
apical palpomeres slender, eye distance 1.14 times maximum eye diameter. Pronotum with well developed costae, surface mostly mat, only middle part weakly shining. Scutellum flat, emarginate at apex. Elytra parallelsided, with well-developed primary and secondary costae. Elytral cells weakly transverse, regular. Male genitalia with dorsoventrally flattened phallus and spiral sclerite of internal sac (Figs 33-34). Female unknown.

Differential diagnosis. M. yoshioi is the only species in Sulawesi with yellow pronotum and elytra and secondary elytral costae present. Male genitalia enable sure identification (Figs 33-34). The male genitalia are similar to those of M. isarogensis (Figs 13-14).

Measurements. Holotype. BL $11.3 \mathrm{~mm}$, WH $2.34 \mathrm{~mm}$, PW $1.82 \mathrm{~mm}$, PL $1.58 \mathrm{~mm}$, Edist $0.73 \mathrm{~mm}$, Ediam $0.64 \mathrm{~mm}$.

Type material. Male, holotype, Tjamba, Zuid Celebes, Doherty, viii, ix (BMNH).

Etymology. The name "yoshioi" is a patronym in honour of Masanobu Yoshio (Hirakata, Osaka Pref.).

Distribution. South Sulawesi.

Remark. The specimen designated here as the holotype of M. yoshioi was identified by Kleine as M. cribripennis Waterhouse, 1879. We studied several specimens from Moluccas and they are different. The type of M. cribripennis is a female (Fig. 31) and more extensive material will be necessary for any further study of the Moluccas fauna.

ACKNOWLEDGEMENTS. The taxonomical part of the study was supported by a grant to L. B. from the Czech Grant Agency (Project 206/03/0982) and a grant under Colparsyst Project (MNHN, Paris). The molecular phylogeny of Metriorrhynchus was studied under a project of the Japan Society for the Promotion of Science (P02203). The following individuals and institutions are gratefully acknowledged for loans of material: W. Tomaszewska (ZMPA, Warszawa), M. Kerley (BMNH, London), J.J. Ménier (MNHN, Paris), O. Jaeger (SMTD, Dresden), and B. Viklund (NHRS, Stockholm). We are obliged to all colleagues who gave in our disposal the material fixed for molecular analyses. They are L. Dembicky (Brno), E. Jendek (Bratislava), C. Reid (Sydney), A. Riedel (Karlsruhe), and S.A. Slipinski (Canberra).

\section{REFERENCES}

BocÁK L. 1998a: A revision of the genus Microtrichalus from the Philippines (Coleoptera: Lycidae). Eur. J. Entomol. 95: $417-428$.
BocÁk L. 1998b: Nomenclatural notes on taxa of the family Lycidae described by Guérin Méneville (Insecta: Coleoptera). Ann. Zool. 48(3/4): 245-251.

BocÁK L. 2000: A revision of the genus Diatrichalus Kleine from the Philippines (Coleoptera: Lycidae) Raffles Bull. Zool. 48(1):11-16.

BocÁK L. 2002: Revision and phylogenetic analysis of Metriorrhynchinae. Eur. J. Entomol. 99: 315-351.

BocÁK L. in press: A revision of Metriorrhynchus (Coleoptera: Lycidae) from the Greater Sunda Islands and continental Asia. Raffles Bull. Zool.

BocÁK L. \& K. Matsuda 1998: A review of the Metriorrhynchus thoracicus group (Coleoptera: Lycidae). G. Ital. Entomol. 8[1997]: 409-415.

BocÁK L. \& K. MATSUdA 2003: Review of the immature stages of the family Lycidae (Insecta: Coleoptera). J. Nat. Hist. 37: 1463-1507.

Dalman J. W. 1818 in Schoenherr C.J.: Synonymia Insectorum oder Versuch einer Synonymie aller bisher bekannten Insecten ... Appendix ad Synonymia Insectorum. Bd. 1, Theil 3. Scaris: Lewerentz. 266 pp.

Hall R. \& D. Blundell 1996: Tectonic Evolution of Southeast Asia. Geol. Soc. Spec. Publ. No 106. London.

HuelsenbeCK J.P. 2000: MrBayes: Bayesian Inference of Phylogeny. Distributed by author. Department of Biology, University of Rochester, NY, USA.

KLeINE R. 1926: Die Lyciden der Philippinen-Inseln. Philipp. J. Sci 31(1): 33-114.

Kleine R. 1933: Lycidae. Pars 128. In Junk W. \& Schenkling S. (eds): Coleopterorum Catalogus. W. Junk, Berlin, pp. 1-145.

MroczKowsKi M. 1959: List of type specimens in the collection of the Institute of Zoology of the Polish Academy of Sciences in Warszawa. Ann. Zool. 18(2): 11-63.

PIC M. 1922: Contribution à l'étude des Lycides. L'Echange 407: 13-16, hors-texte.

PIC M. 1925: Malacodermes exotiques. L'Echange 420: 9-12, hors-texte.

Simon C., Fratti F., Beckenbach A., Crespi B., Liu H. \& Flook P. 1994: Evolution, weighting, and phylogenetic utility of mitochondrial gene sequences and compilation of conserved polymerase chain reaction primers. Ann. Entomol. Soc. Am. 87: 951-701.

Swofford D.L. 1999: PAUP*; Phylogenetic Analysis Using Parsimony. Version 4.0b10. Sunderland, MA: Sinauer.

Vogler A.P., De Salle R., Assmann T., Knisley C.B. \& Schultz T.D. 1993: Molecular population genetics of the endangered tiger beetle, Cicindela dorsalis (Coleoptera: Cicindelidae). Ann. Entomol. Soc. Am. 86: 142-152.

Received January 3, 2005; revised and accepted August 10, 2005 